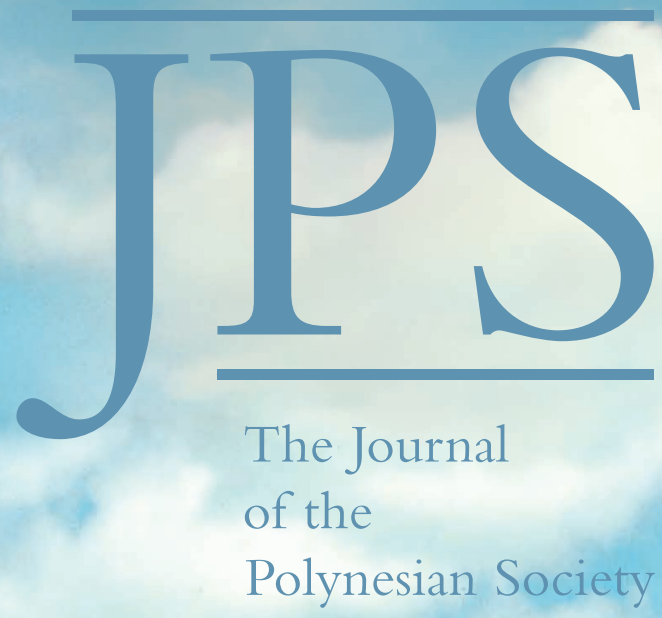

VOLUME 127 No.3 SEPTEMBER 2018

THE POLYNESIAN SOCIETY

THE UNIVERSITY OF AUCKLAND

NEW ZEALAND

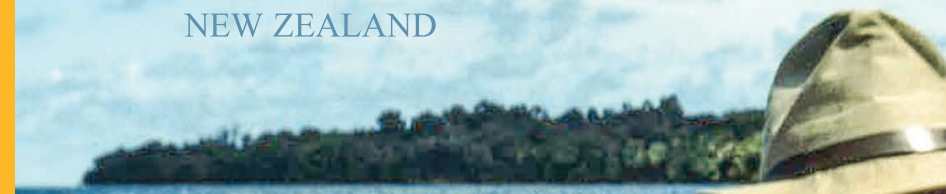

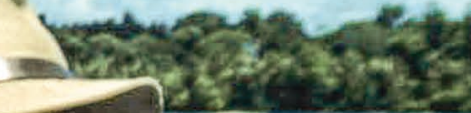

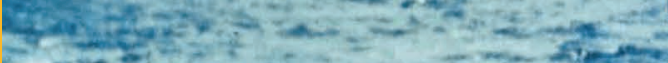

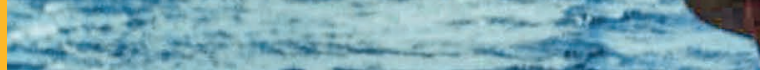

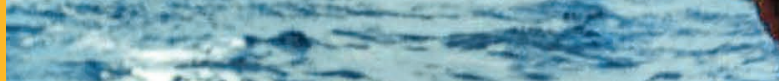

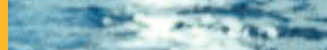

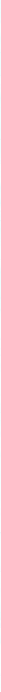




\title{
VOICES ON THE WIND, TRACES IN THE EARTH: INTEGRATING ORAL NARRATIVE AND ARCHAEOLOGY IN POLYNESIAN HISTORY
}

\author{
PATRICK VINTON KIRCH \\ 2018 Nayacakalou Medal Recipient \\ University of California, Berkeley
}

The Polynesian peoples have long been noted for their propensity to encode the rich traditions of their ancestors in oral narrative accounts, often memorised by priests or other specialists, and passed down orally from generation to generation. Anthropologists refer to these as oral traditions, oral history or oral narratives, although they are also often categorised as "legend" or "myth", terms that tend to dismiss their value as witnesses of real human affairs - that is to say, of history. In this lecture, I focus on a particular form of Polynesian oral narrative or oral history - one that is fundamentally chronological in its structure in that it is explicitly tied to a genealogical framework.

Now I confess that I am not a specialist in oral tradition, a subject that is sometimes subsumed under the discipline of "folklore". I am by training and by practice, over nearly half a century now, an archaeologist first and foremost. But I am also an anthropologist who believes in the holistic vision of that discipline as conceived by such disciplinary ancestors as Alfred Kroeber and Edward Sapir at the beginning of the 20th century. While this may make me something of a living fossil in the eyes of younger scholars who hew to narrower subdisciplinary paths, my holistic training and predilections incline me to see the value in working across and between the different branches of anthropology. I have thus taken as my topic for this lecture the relationship between oral narrative - especially that of the genealogically based oral-history kind - and the material remains of the past that are the archaeologist's purview. Can those traditional narratives - those "voices on the wind", as folklorist Katherine Luomala (1955) once felicitously called them-be fruitfully combined with the material traces that we wrest from the Polynesian earth?

I will explore this question through four case studies involving my own fieldwork on as many different Polynesian islands, specifically Futuna, Tikopia, Niuatoputapu and the Hawaiian Islands (especially Maui). But first, let me provide some essential background into the changing roles that oral narrative played in Polynesian anthropology during the 19th and 20th centuries. 


\section{WRITING HISTORY THROUGH TRADITION}

The oral-aural relating of traditions from generation to generation had gone on within Polynesian societies for centuries, indeed probably thousands of years, a practice quite likely tracing back to their Lapita ancestors. With the arrival of Europeans and the subsequent introduction of alphabets, dictionaries and printing presses, many Polynesians rapidly embraced literacy as the 19th century progressed. In Hawai ' $i$, Kānaka Maoli scholars such as Davida Malo and Samuela Kamakau set to paper extensive accounts of the previously oral mo 'olelo 'histories or traditions' (Kamakau 1961; Malo 1951). In Mangaia, the native pastor Mamae similarly wrote down the traditions of his island (Reilly 2003); in Tahiti, the Ari' $i$ Taimai made a similar record (Arii Taimai 1964). Many other examples could be cited.

Western scholarly interest in Polynesian traditions reached a peak toward the later 19th century that is marked, among other events, by the founding of the Polynesian Society in New Zealand in 1892 and the Bernice P. Bishop Museum in Honolulu in 1889. The work of Abraham Fornander (1878) offers a good example of how Polynesian narrative history was used in the 19th century to construct interpretations of the Polynesian past (see also Grey 1885; Smith 1910, 1921). Fornander arrived in Hawai' $i$ in 1838, married a Hawaiian woman of chiefly descent from Moloka'i Island, became fluent in the Hawaiian language, and began avidly collecting the Hawaiian mo 'olelo. Fornander's three-volume An Account of the Polynesian Race (1878) relied upon dubious linguistic comparisons to trace Polynesian origins back to South Asia. But ignoring these wilder speculative interpretations and focusing solely on Volume II of Fornander's Account, we find a richly detailed outline of Hawaiian history from the time of the arrival on $\mathrm{O}^{\prime}$ ahu Island - according to Hawaiian traditions - of the chief Maweke. Using the chronology provided by the chiefly genealogies, Fornander writes of Maweke:

He lived twenty-seven generations ago, counting on the direct line through the Oahu chiefs his descendants, or from twenty-six to twenty-eight generations ago, counting on the collateral Hawaii and Maui lines of chiefs, or approximately about the earlier and middle part of the eleventh century. (Fornander 1878, Vol. II: 47)

Beginning with Maweke and his descendants, Fornander recounts a detailed, island-by-island history of the main chiefly families, their marriages, feuds, wars, conquests and other achievements and misdeeds, down to the famous Kamehameha I and his conquest of the Maui and $\mathrm{O}^{\prime}$ ahu kingdoms. Fornander's Volume II is intended to be a real history of named persons, situated within the temporal framework provided by the chiefly genealogies. 
In Fornander's own words: "If I have succeeded in showing that the Hawaiians had a history of their past, and a history worth preserving, my labour will not have been in vain" (1878, Vol. II: 349$)$.

Fornander and others laid a foundation that would be drawn upon and greatly expanded by the work of scholars in the emerging academic field of anthropology at the beginning of the 20th century. A burst of anthropological fieldwork throughout Polynesia was launched in 1920 at the instigation of the Bishop Museum's Director, Herbert E. Gregory. The Bayard Dominick Expeditions (1920-21) were followed by additional fieldwork by Bishop Museum staff and affiliates from other institutions, ranging across Polynesia from Tonga and Sāmoa through central Eastern Polynesia, to remote Rapa Nui (see Hiroa 1945 for a summary). A major question underpinning this research program was the so-called "problem of Polynesian origins" (Gregory 1921). The field teams avidly collected oral narratives, especially those of chiefly genealogies and the histories of elite marriages, conflicts, conquests and the like, much as Fornander had obtained for Hawai ${ }^{i} i$.

This emphasis on genealogically based oral narratives is exemplified in the work of the great Māori anthropologist Te Rangi Hiroa, who in 1935 succeeded Gregory as Director of the Bishop Museum. Hiroa's Mangaian Society (Hiroa 1934) serves as a case study, although his work in other islands such as Mangareva (Hiroa 1938) or Tongareva (Hiroa 1932) is equally instructive. On Mangaia, Hiroa augmented his own inquiries into "family pedigrees" (1934: 26) through access to an important manuscript written by the Mangaian pastor Mamae. Significantly, Hiroa refers to those narratives concerning the earliest human settlers to the island, the children of Vatea, followed by an invasion by Rarotongans, as "mythological" accounts, not as history. But the next major section of his monograph is entitled "History", commencing with a discussion of the importance of genealogical records: "The family pedigrees characteristic of Polynesia are of much greater value in tracing a chronological record than are the lists of titleholders which have sometimes been used" (1934: 26). His 58-page long discourse on Mangaian history tied to this genealogical structure is a masterful account of the ebb and flow of competing tribes, such as the Ngati-Vara and Akatauira, as they vied for power and control of land. As with Fornander before him, Hiroa clearly saw these Mangaian narratives as history, not myth or legend.

In his masterwork, Vikings of the Sunrise, Hiroa critically discusses the role of genealogies and oral narratives as the basis for Polynesian history (Buck 1938: 21-25), observing first that "the oral transmission and memorizing of genealogies was a routine part of the Polynesian system of education" (1938: 21). Hiroa asserts that "the recital of genealogies was an established technique in social life and served as a chronology of historical events associated with 
the sequence of ancestors", but then thoughtfully adds, "how far back this sequence may be relied upon depends not only on the limitations of human memory but also on the interruptions that may have occurred to direct and orderly transmission of titles" (1938: 22). He does not hesitate to criticise earlier writers, such as S. Percy Smith, who had used clearly mythological accounts to trace the Polynesians back to origins in India. Of such fanciful interpretations, Hiroa writes: "With all my love for my mother's stock, my father's unbelieving blood gives me pause" (1938: 25). But for Hiroa, the genealogically based narratives that he and others painstakingly obtained from individual Polynesian informants through their fieldwork, and partly from previously written "native texts", provided not only an accurate source-but effectively the only source-for constructing the histories of Polynesian societies.

\section{WRITING TRADITION OUT OF HISTORY}

Why was so much emphasis placed on genealogy and oral narrative in this initial period of intensive anthropological research in Polynesia? And why did the Bishop Museum scholars and their collaborators rely so intensively on genealogically based accounts to construct their histories of island societies? After all, the Bayard Dominick Expeditions and other Bishop Museum field teams also included archaeologists. Why did archaeology not contribute more fundamentally to this effort to reconstruct Polynesian history? The answer is simple: the archaeologists of the first half of the 20th century working in Polynesia lacked any independent means of establishing chronology. In the absence of pottery, it was assumed that excavation was pointless; there was no evident way to directly date the stone remains of marae, heiau, langi 'temples' and other structures that the archaeologists devoted their time to painstakingly surveying and mapping. Little wonder that Te Rangi Hiroa himself regarded archaeology as a "dry subject" (Hiroa, in Sorrenson, ed., 1986-88, Vol. III: 160).

Shortly before his death in 1951, Hiroa personally witnessed the dawn of a new era in Pacific archaeology, one that would reject his genealogically based approach to Polynesian history and replace it with a new paradigm, one rooted quite literally in the hard science of the new Atomic Age. Willard Libby, a chemist who had participated in the Manhattan Project that developed the atomic bombs that destroyed Hiroshima and Nagasaki, announced in 1947 that he had developed a method of "radiocarbon dating". One of the first to respond to Libby's call for archaeological samples was the Bishop Museum's Kenneth P. Emory, who had begun stratigraphic excavations in the Kuli'ou'ou Rockshelter on O'ahu Island. As related by Emory's biographer, Bob Krauss: 
On February 19, 1951, Buck [Hiroa] called Kenneth to his office and read aloud a letter just received from Chicago. Libby had dated Kenneth's sample of charcoal from the cave at Kuliouou at A.D. 1004, plus or minus 180 years. It was the first carbon date for Polynesia. "Boy, was I excited," said Kenneth later. "Immediately it opened a whole new vista of possibilities." (Krauss 1988: 338)

Supplied now by the physicists with the essential tool they previously lacked - a method for directly dating materials excavated from Polynesian archaeological sites - the archaeologists seized the day. The 1950s and early 1960s were heady times for Polynesian archaeology, as the old assumption that excavation was pointless crumbled in the face of rich new finds in stratified sand dunes and rockshelters, with the fishhooks, adzes, pendants and other objects all fitting into the new chronological sequence provided by radiocarbon dating (see Kirch 2017: 23-28 for a summary of this period in Polynesian archaeology).

One of the first to explicitly question - and reject - the old paradigm of Polynesian history based on the traditional oral narratives was Robert Carl Suggs, a young American archaeologist who excavated sites on the Marquesan island of Nuku Hiva in 1956-57 (Suggs 1961). In an article titled "Historical traditions and archeology in Polynesia," Suggs called into question "the traditionalist approach which long dominated Polynesian prehistory" (Suggs 1960: 764). Drawing on the results of emerging archaeological work in New Zealand and Hawai' $i$, as well as upon his own Marquesan research, Suggs drew attention to major discrepancies in the dating of initial human arrival in the islands. ${ }^{1}$ For the Marquesas, Bishop Museum ethnographer E.S.C. Handy had arrived at an estimated initial settlement date of approximately AD 950, based on traditional genealogies (Handy 1923). Suggs, who had obtained radiocarbon dates of nearly 1,000 years older from the Ha'atuatua site, noted that "there is unfortunately no such agreement apparent between the dates of Marquesan settlement which were reached by genealogical counts and those obtained by radiocarbon age determinations on samples from our earliest excavated site" (1960: 767). ${ }^{2}$ For Suggs, the conclusion was self-evident: the genealogically based oral narratives, or as he was inclined to call them, the "legends", did not offer a suitable basis for a scientifically rigorous (pre)history. ${ }^{3}$

But the new scientifically based archaeology with its emphasis on radiocarbon dating and stratigraphic excavation was not the only assault on the primacy previously accorded Polynesian oral narrative history. Hiroa, Handy, Gifford, Burrows and others of the first phase of Polynesian ethnographic research in the 1920s and 1930s had regarded the reconstruction of the "preEuropean" cultures and their histories as a primary research goal. But by the 1940s and 1950s, cultural anthropologists were losing interest in this kind of 
"salvage ethnography", and indeed, in historical reconstruction in general. The structural-functionalist school championed by Bronislaw Malinowski, and elaborated by Raymond Firth, Alfred Radcliffe-Brown and Margaret Mead, regarded the historical ethnology of Hiroa and his colleagues as quaint and old-fashioned. ${ }^{4}$ But headier critiques were to come, emanating from Paris, through the influential writings of Claude Lévi-Strauss, the so-called "father" of structuralism, the new paradigm that rapidly swept into Anglophone anthropology in the late 1960s and into the 1970s and 1980s, in part through the influential writings of its English advocate, Sir Edmund Leach of Cambridge University.

For Lévi-Strauss and Leach, oral traditions were a source of insight into the structures - usually thought to be dualistic, or quadratic — of the human mind. They were not to be taken as historical accounts, but as timeless myths - origin charters - constructed according to the fundamental dualistic nature of human cognition. Leach, one of the first to introduce English anthropologists to the new French structuralism, did not work in Polynesia. But this did not stop him from offering a searing critique of one of the last efforts to draw upon a body of Polynesian oral narratives as history - specifically Sir Raymond Firth's History and Traditions of Tikopia, published by The Polynesian Society in 1961, based on Firth's Tikopia fieldwork in 1928 (Firth 1961). Firth regarded those Tikopia traditions that are genealogically grounded to be a kind of "quasi-history", by which he meant that they were rooted in the real actions of people who had at one time lived and died on the island. To this claim, Leach objected vehemently. Leach asserted that "almost the whole of the material present here [by Firth] under the label 'quasi-history' is true mythology" (Leach 1962: 274). Leach continued: "It is at least equally plausible that, for the Tikopia, all time more remote than 'living memory' belongs to an undifferentiated past, and that though events in this past are 'ordered' - by means of genealogy and the like - no particular event can properly be regarded as earlier or later than any other" (1962: 274).

And then came the crushing blow, in the following passage dealing with Firth's careful analysis of the wars between Nga Ariki (ancestors of the present Tikopia) and their rivals Nga Ravenga and Nga Faea, conflicts that Firth regarded as actual historical events:

I should myself have supposed that nothing could be more obvious than that the Nga Faea are an entirely mythical people filling an entirely mythical role, yet Firth having described the traditions relating to their elimination proceeds to argue as if these events had actually occurred 'two centuries ago' (p. 142). Of course there were events which actually occurred in Tikopia two centuries ago but I see no grounds for supposing that any of them are recorded anywhere within the covers of this book. (Leach 1962: 276) 
With scientific archaeology rejecting genealogically based oral narrative history in favour of its radiocarbon-based chronologies, and with the dominant structuralist paradigm in socio-cultural anthropology prepared to classify all "traditions" as timeless myth, there was little scope left for the incorporation of oral tradition in Polynesian history. The archaeologists rejected the oral histories as unreliable, while the cultural anthropologists were simply no longer interested in history at all. Despite a few exceptions, this is largely how the field looked when I came into it as a young student in the mid-1960s and 1970s. ${ }^{6}$

How then, as a young, aspiring archaeologist, deeply immersed in the prevailing scientific paradigm of the "New Archaeology" of the late 1960s and early 1970s, did I come to be engaged with Polynesian oral narratives? The answer is simple: I went to do fieldwork in several islands where oral tradition was still quite alive and vibrant, and where the people who graciously allowed me to work on their lands and dig in their ancient sites took pains to make me understand that the stone alignments and backrest slabs and middens that I was studying were intimately connected with them and their histories, as these had been and indeed continued to be transmitted from generation to generation. So let me recount some of those experiences of fieldwork at the intersection of archaeology and tradition, the crossroads of voices from the past with the traces from the earth.

\section{FUTUNA AND ALOFI: TRADITIONS OF WAR AND CONQUEST}

Forty-four years ago, I sailed on a small French freighter from Nouméa to the islands of Futuna and Alofi, part of the French Territory of Wallis and Futuna, to carry out an "ethno-archaeological" study of taro irrigation and other agricultural practices for my doctoral project at Yale University. Partly on the advice of Doug Yen, I had chosen Futuna because its agricultural system was described to me as still more or less traditional, not influenced by commercial cropping or plantation agriculture. Indeed, Futuna in 1974 was linked to the World System by a tenuous thread, despite some of its male inhabitants periodically migrating to New Caledonia for paid work in the nickel mines and smelters.

Nuku Village, where I took up residence in a small bachelor's hut, had no electricity (nor did any other village); most of the houses were of traditional pole-and-thatch construction with open sides and gravel floors, most cooking was done in separate cookhouses with an earth oven, the water source was a single pipe leading to a large concrete basin where everyone bathed communally in the late afternoon. Most importantly, there was no radio, no television. I paint this scene merely to emphasise that in the Futuna of 1974 that I experienced for some eight months, social interaction - the gathering 
of kinsfolk at the water tank, in the cookhouses, and sitting on woven mats around the communal meal fresh from the earth oven - was characterised by people constantly interacting verbally. They talked about the weather, they shared gossip, they discussed the ripening of the breadfruit and the death of the old man in the neighbouring household. And sometimes, they talked about the past, sharing stories and narratives, about persons who had walked the village paths before their time, about events that had shaped this same landscape over previous generations. Oral narrative was still very much a vibrant part of Futunan culture and society.

Most often, I began to hear these traditional narratives while joining in the evening kava drinking at the meeting house of the Tu'i Sa'avaka, one of Nuku's titleholders who welcomed this young papalangi 'foreigner' into his kava circle. Futunan traditions were not, I admit, my main interest, but neither was I disinterested in them. I had with me a copy of Edwin Burrows's Ethnology of Futuna in which he had devoted a section to "traditional history" (Burrows 1936: 26-56). Upon close reading, I discovered references to places and sites that I was encountering on the ground, as an archaeologist. One such site was A-fili, a fortified ridge in the hills above Nuku (Burrows 1936: 126), associated with traditions of a rebuffed Tongan invasion and of several wars between the Sigave and Alo chiefdoms.

It was then my great luck to be introduced to Sosefo Sekemei, an elder of Vele Village in Alo. Inviting me to tour Alofi Island with him over five days in June of 1974, Sosefo opened my eyes (I should say my ears) to the significance of oral tradition and narrative history in making sense of the Futuna-Alofi archaeological landscape. With Sosefo as my guide, we climbed up the limestone escarpment to the Asoa uplands inland of Vele, where he showed me the backrest stones, still standing, of the malae 'ceremonial plaza' of Lalolalo, former seat of Veliteki and Niuliki, successive paramount chiefs of Alo in the early 19th century. We continued on to the summit of the karstic Asoa ridge, where another malae plaza was again marked by upright slabs. Sosefo described this place, known as Kelemea, as the residence of Papa, a renowned warrior of the pre-European period.

Returning to the shore, we loaded up an outrigger canoe and paddled across the narrow strait to Alofi. Sosefo guided us across the upland plateau to Loka, the abandoned seat of the Mauifa chiefs prior to their defeat and the extermination of the Alofi population in a war some decades prior to the arrival of the Catholic missionary Père Chanel in $1837 .{ }^{7}$ This site, with a malae covering about $1,200 \mathrm{~m}^{2}$, is the most impressive monumental structure on either Alofi or Futuna (Kirch 1994: 239-41, Figs 99, 100). Sosefo pointed out the row of upright backrest slabs lining one side of the malae, the curbstone outline of Mauifa's residence and the grave of the first titleholder of the Mauifa line (Fig. 1). 


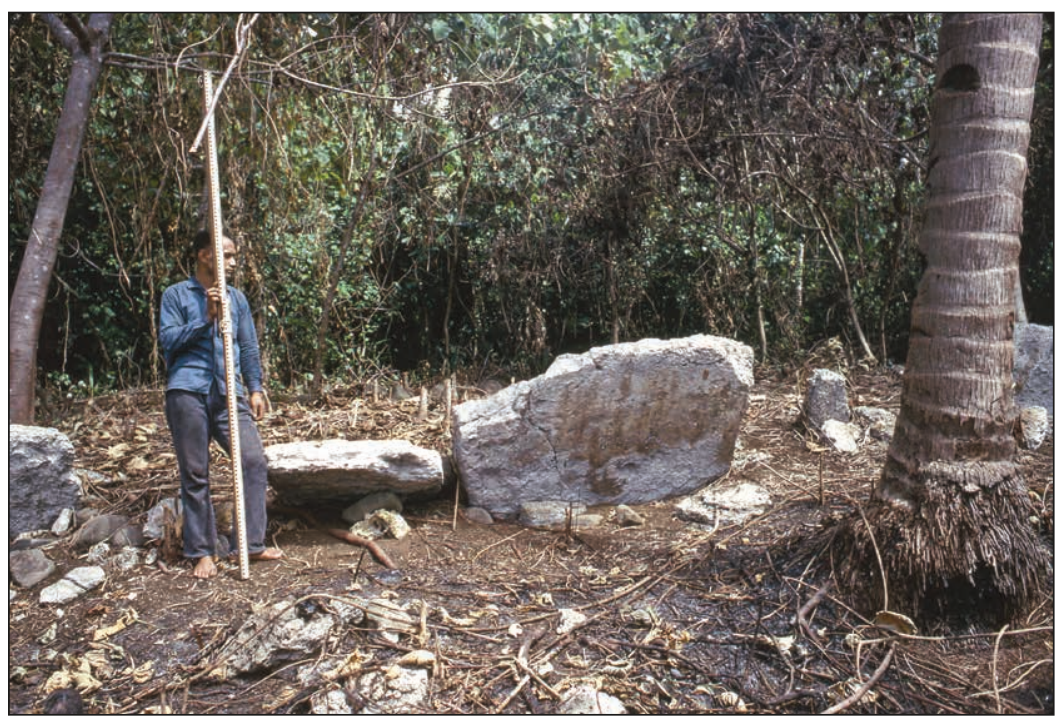

Figure 1. The alignment of cut-and-dressed limestone backrest stones along the rear of the malae plaza at Loka, on Alofi Island. Sosefo Sekemei identified this as the former seat of the Mauifa line of paramount chiefs of Alofi Island.

I regret now that I did not spend more time with Sosefo, did not ask him more questions, did not seize the opportunity to have him share - as he was so evidently willing to do-his deep knowledge of Futunan traditions. I was a young man in a hurry: I had a dissertation to write about Polynesian irrigation and ecology. But what I did glean from that wizened elder, and from the traditions recounted by the $\mathrm{Tu}^{\prime} \mathrm{i}$ Sa' avaka and others, was an initial appreciation of the value of oral tradition for understanding and interpreting Polynesian archaeological landscapes.

For when I began to write up the results of my fieldwork back in Honolulu, I found that the traditional narrative history provided essential keys to unlocking the fundamental tensions that I later came to characterise as "the wet and the dry", an ecological and agricultural contrast that not only helped to determine the outcome of late Futunan history, but has played out in similar scenarios across many other Polynesian landscapes (Kirch 1975, 1994). My agro-ecological studies had revealed a striking contrast between western Futuna (the Sigave chiefdom), where the volcanic terrain and permanent streams allowed for an economy dominated by intensive irrigation, and 
eastern Futuna along with Alofi (the Alo chiefdom), where the limestone terrain limited irrigation to a few small pockets and the agricultural economy was based primarily on shifting cultivation of dryland crops, especially yams and dryland taro. The Futunan traditional history offered independent support for my hypothesis that this ecological tension between "the wet and the dry" had played out over the course of the island's history in terms of a series of competitions between the main political factions, a series of internal struggles for control of land and resources.

Based on the traditions collected by Burrows $(1932,1936)$ and augmented with my own conversations with Sosefo Sekemei and others, I synthesised the traditional history of what today comprises the Alo chiefdom into a single diagram (Kirch 1994: 208, fig. 89). The diagram traces six main chiefly descent lines in what were originally as many independent political (and territorial) units, and shows how-over time and through conquestthese successively merged to become one single, powerful chiefdom under the reigns of Veliteki and Niuliki, just prior to the arrival of the Catholic missionaries in $1837 .{ }^{8}$ Especially poignant to me was that I had been able to directly link the traditions of both the Lalolalo chiefs (the Fakavelikele line) and the Loka chiefs (the Mauifa line) with actual archaeological sites, specifically the malae that had been their ceremonial seats. The traditions and the archaeology meshed - together they told a story that was more powerful and compelling than either by itself.

\section{TIKOPIA: DISENTANGLING MYTH FROM HISTORY}

In May of 1977, some three years after my Futunan fieldwork, I landed on the beach at Matautu, in the Faea district of Tikopia, the Polynesian Outlier made anthropologically famous thanks to the unsurpassed ethnographic talents of Sir Raymond Firth. As in Futuna, my research goals in Tikopia were not in the first instance directed at traditional history. But I had read Firth's We, The Tikopia (Firth 1936), and who could not set foot on that exquisitely beautiful little island, with its peak of Reani overshadowing the deep blue-green crater lake Te Roto, and not be immediately enmeshed in one of the most vibrant of Polynesian societies? For Tikopia in 1977-this was before the island became a stopping point for boutique cruise-ship tourism - was indeed but little changed from what Firth had experienced and described during his sojourn a half century earlier. Not a single trade store, no resident missionaries (although the island had finally converted to Christianity in 1957), an entirely self-contained subsistence economy, and a society still organised around its traditional clans and governed by the four hereditary ariki, the chiefs of Kafika, Tafua, Taumako and Fangarere (in ranked order). 
It was the Ariki Tafua - traditional chief of Faea district - and his family who welcomed Doug Yen and me on the beach at Matautu, incorporating us into their household. Together with the other ariki 'chiefs' and the council of maru 'elders', Tafua acceded to our request to carry out an archaeological study of the island. After settling into the bachelor house, Taraula, that they graciously cleared out for us, I began to reconnoitre the Faea lowlands, searching along the muddy paths leading inland, soon encountering a number of low alignments of angular basalt cobbles, seemingly the curbstone foundations of former houses. These lay inland of the present coastal hamlets, a short distance behind the long dart pitch known as Te Marae Lasi. The Ariki Tafua and his sons told me that these structures were noforanga, the foundations and vestiges of the former village of Nga Faea, the original occupants of Faea district who had been forced to flee the island after an attack by Nga Ariki, the ancestors of the present Tikopia (Firth 1961: 136-43).

Nga Faea: the very people whom Edmund Leach, in spite of never having set foot on Tikopia, condescended to describe in his review of Firth's History and Traditions of Tikopia as "an entirely mythical people filling an entirely mythical role" (Leach 1962: 276). The Ariki Tafua certainly did not regard Nga Faea as mythical, recounting to me the same traditions that his father had related to Firth, of how the Nga Faea chief Tiako, held aloft in his canoe by his supporters, called out to the victorious Nga Ariki to respect and honour Feke, the Octopus God, to assure the fertility of land and reef. The rites of the Octopus God had continued to be practiced into the early 20th century, as witnessed by Firth (1967).

The alignments of hard basalt that became more evident as the Ariki Tafua's kinsmen helped me to clear away the brush and weeds were anything but mythological. There were three distinct, rectangular house foundations, framing a kind of courtyard (Kirch and Yen 1982: 69-72, Figs 18, 19, 20). Along the inland side of this court an alignment of 13 upright volcanic slabs formed a classic marae configuration with the slabs serving as backrests for participants in kava ritual (Fig. 2). The Ariki Tafua explained that this complex of houses and the line of backrests was known to them as Takaritoa, having served as the principal marae of Nga Faea. The largest of the volcanic uprights was said to have been the backrest of Pu Perurua, a famous warrior (toa) of Nga Faea.

A short distance from Takaritoa we uncovered another rectangular house foundation, again demarcated by basalt curbstones, in the garden tract called Sinapupu. This, the Ariki Tafua informed me, was called Tarengu, and had been another temple, or "Kafika", of Nga Faea. The structure offered a good opportunity for excavation; the Ariki Tafua willingly agreed to let me commence digging, assisted by his kinsmen (Kirch and Yen 1982: 


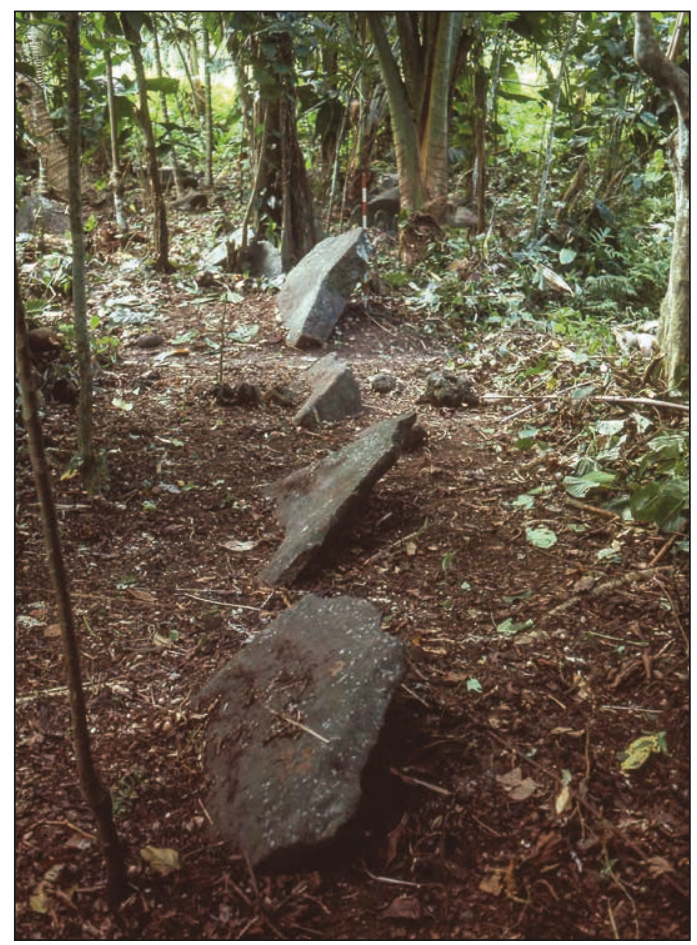

Figure 2. The line of upright basalt slabs forming part of a marae of the Nga Faea at Takaritoa, Tikopia. The largest slab was identified as the backrest of $\mathrm{Pu}$ Perurua, a famous Nga Faea warrior.

93-98). It did not surprise me, given Firth's description of Tikopia temples as sepulchres for the ancestors, when we soon encountered two flexed burials just below the house floor (Kirch and Yen 1982: 110-11, Fig. 40). An entirely "mythical people"? These human skeletons were certainly not mythical. With permission of the Ariki Tafua, a fragment of bone from one of the burials was removed and later radiocarbon dated, yielding Bayesian calibrated age intervals of cal AD 1480-1696 and 1729-1803 (Kirch and Yen 1982: 315; see also Kirch and Swift 2017, Table 5). On the basis of the Tikopia genealogies (using an average of 25 years per generation) Firth estimated that the expulsion of Nga Faea had occurred around AD 1725 (1961: 160). Clearly, the genealogical dating and the radiocarbon date from the Nga Faea temple burial accord very well. 
Before returning to Tikopia in 1978 for a second field season, I used the intervening months to closely read Firth's entire ethnographic corpus, paying special attention to History and Traditions of Tikopia, knowing that I would have a unique opportunity to follow up on leads into the island's traditions and their possible intersections with the archaeological traces I was uncovering. ${ }^{9}$

Now I must stress that a great many of the Tikopia oral traditions are indeed mythological in character. The Tikopia distinguish between tara tириа, which are typically indexed to genealogies and regarded as historical accounts, and kai, stories that are generally timeless. Many important kai deal with an ancient era when, as the Tikopia say, e oro ki a tangata kae oro ki a nga atua, when people "went as men and went as gods" (Firth 1961: 25). Such kai include the Kai Tapu, or Sacred Tale, recounting "the adventures of Tafaki and Karisi [known together as $\mathrm{Pu} \mathrm{Ma}$ ], the gods who are basic to the ritual of Kafika clan" (1961: 13). The Sacred Tale is an origin myth, essential, as Firth explains, to Tikopia cosmology and ritual beliefs. So yes, there is much mythology in the Tikopia traditions, but just as the Tikopia themselves have no trouble disentangling myth from history, so we as astute anthropologists should be able to readily discern the same distinctions in their corpus of oral narratives.

But let me return to the category of tara tupua, and especially to those genealogically indexed narratives that deal with the origins and histories of the several clans and lineages. Tikopia traditions offer a complex set of stories relating to lineage origins - some mythological and others clearly historical. Of the 23 lineages headed either by one of the four ariki or by a ritual elder, Firth writes that "five claim autochthonous descent, six claim to be segmented from the various chiefly lineages, four claim to be residual from the earlier inhabitants, Nga Ravenga and Nga Faea, and eight claim that their founders were immigrants from overseas" (1961: 85). Among the places cited as origins for these immigrant lineages are Tonga, 'Uvea, Rotuma, Sāmoa, Taumako (Duff Islands), Luangiua (Ontong Java), Pukapuka, Somosomo and Valua (Banks Islands). Importantly, Firth observes that "the period of their arrival has a certain consistency; it was well after the initial peopling of the land by the gods, when for the most part the context described was an ordinary human one, and the leading figures were to be regarded as ordinary mortals" (1961: 86-87). The immigrant founders of these lineages are typically situated at what Tikopia call the fokinga, or "return point" in the kava ritual formulae, "the point at which the ancestral line begins to emerge from the shadowy citation of names alone to the period at which the personalities involved have begun to take on shape, with a body of information about their doings and temperament ... they are people, not just labels" (1961: 87). In short, they are the starting points for what the Tikopia regard to be real historical accounts of founding lineage ancestors. 
Let us explore in a little more depth the origin traditions of Taumako, the line of the third-ranked ariki. Firth was told in 1929 that the Taumako line traced its origins back 12 generations, to the arrival of a chief named Te Atafu, who hailed from Tonga (Firth 1961: 88-89; see also Kirch and Yen 1982: 342-43). Te Atafu married a daughter of the Ariki Kafika; their son Rakaitonga, later known as Pu Lasi (literally "Great Ancestor"), became the first Ariki Taumako. Te Atafu eventually left Tikopia, while his son Pu Lasi rose to fame in part through fending off several attempted invasions by other would-be Tongan intruders (Firth 1961: 110-11). Toward the end of his life, $\mathrm{Pu}$ Lasi retired to live on the summit of Fongatekoro, literally "fortress hill", a volcanic massif that rises sheer above the hamlets of Ravenga, and there upon his death he was interred (Fig. 3).

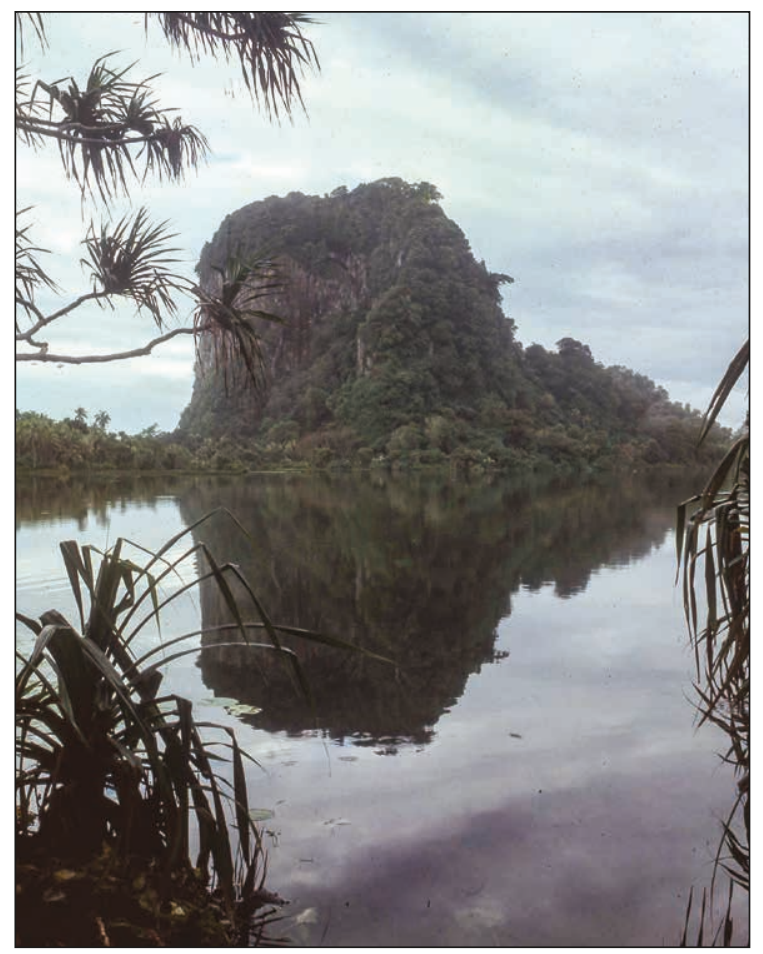

Figure 3. The massif of Fongatekoro (viewed here across Lake Te Roto from the sacred district of Uta) figures in Tikopia traditions as a fortress. Pu Lasi is buried in a small platform on the summit of Fongatekoro. 
I was told that the gravesite of Pu Lasi could still be seen atop Fongatekoro; with the assistance of two Taumako friends, I scaled the precipitous ridge leading to the summit in order to verify this claim. Indeed, the tomb of $\mathrm{Pu}$ Lasi consists of a small platform about 1 by $1.2 \mathrm{~m}$, with volcanic facing slabs $30 \mathrm{~cm}$ high, covered with white sand (Kirch and Yen 1982: 73, Fig. 21). The tops of two femurs had been slightly exposed by erosion; we covered them over with sand.

Later during the 1978 field season, I had occasion to visit the aged and by now blind Ariki Taumako, who had taken to living in Raniniu, the last standing temple or god house (fare tapu) in Tikopia, situated near the shore in his hamlet of Potu sa Taumako. The ariki, who had reluctantly converted to Christianity following the devastating cyclones of 1952-53, had stubbornly refused to destroy this fare tapu; removing some of the sacred contents that had previously been held in the main Taumako temple of Resiake in Uta, he had placed them in Raniniu. Entering Raniniu through the low doorway and allowing my eyes to adjust to the dim light, it became clear that this was a special structure, in spite of its exterior appearance as an ordinary thatched house (Kirch 2015: 138-40). Carved representations of yellowfin tuna ornamented the main posts, while the rafters were decorated with fakataratara 'nubbins'; a kava bowl sat in one corner.

Responding to my queries, the Ariki Taumako reiterated the tara tupua of Taumako as recounted by Firth, but added a few critically important details. First, he said that while known in Tikopia as Te Atafu, his ancestor's Tongan name had been Tui Tatafu. From my previous work in Tonga (see below), I knew that Tatafu was a prominent title in the genealogies of the Tongan paramount lines (Gifford 1929: 30, 35, 84; see also Bott 1982), as well as in the chiefly traditions of 'Uvea, which came under Tongan domination (Burrows 1937: 29). Indeed, the Tatafu title is closely linked to the protohistoric Tongan domination of 'Uvea, Niuafo 'ou and Niuatoputapu, the first titleholder being the son of the Tongan lord Tu'i Ha'a Takalaua Fotofili, who was sent to 'Uvea to oversee the quarrying of slabs to be used in a burial mound (langi) for the Tu'i Tonga (Bott 1982). His son, the second titleholder, became the ruling chief of Niuafo'ou; the title also appears as the name of the son of Pungakaitafola, the fourth Ma'atu or lord of Niuatoputapu.

When I asked the Ariki Taumako whether he knew the names of any of his ancestor's kinsfolk in Tonga, the ariki told me that Tui Tatafu (Te Atafu) had two brothers, named Tui Pelesa and Tui Saapai. This was quite stunning, for those are unquestionably the Tikopian phonetic transliterations of two prominent Tongan chiefly titles. Tui Pelesa $=\mathrm{Tu}$ 'i Pelehake, of the Tongan Faleua line (see Kaeppler 1971a: 182, Fig. 4), while Tui Saapai = Tu'i Ha'apai, lord of Ha' apai and representative in those islands of the Tu'i Tonga. Notably, the Tu'i Ha'apai title has not been used for more than two centuries. 
Now the Ariki Taumako had clearly not read the monographs of Gifford, or Bott, or Kaeppler; what he was sharing with me that morning in Raniniu was, I have no doubt, traditional knowledge that had been passed down in his family line since the time of Te Atafu, 13 generations earlier. Had Te Atafu, his ancestor, actually been a Tu'i Tatafu titleholder? Quite possibly, but if not, then he was certainly someone with a knowledge of Tongan noble titles.

But there was yet other, tangible, material evidence of the historical veracity of the Taumako tara tupua of Tongan origins. I had come to visit the ariki partly because I had heard that he possessed a war club reputedly brought by Te Atafu from Tonga, an object said to be shaped like an eel, and indeed named Te Tuna, a representation of the eel god. When I enquired if I might see the club, the ariki graciously let my friend John and I examine it. The wooden club, about one meter long, clearly old and somewhat termiteeaten, was of classic Tongan form with a narrow base and expanding head, ornamented with simple geometric carving (similar to the "paddle club" illustrated by St Cartmail [1997: 133-34, Fig. 88a]). I regret that I was not able to photograph it. I saw no reason to question the ariki's assertion that the club had been brought from Tonga by his ancestor.

To conclude this discussion of the intersections between tradition and archaeology in Tikopia I will return to the accounts of the wars over land that for two or three generations consumed the groups known as Nga Ravenga, Nga Faea and Nga Ariki, ending with the latter's mastery over the island (Firth 1961: 128-43). Nga Ariki is the collective name for the present Tikopia population, encompassing all of the lineages, despite their varied origins. Nga Ravenga and Nga Faea - regarded by Prof. Leach as "entirely mythological"-were two distinct groups, the first of whom occupied the coastal lands of Ravenga along the southern part of the island, while the latter controlled the highly productive agricultural lands of Faea District on the west and north. Firth was told that Nga Ravenga "were the true autochthones" of Tikopia (1961: 129), while Nga Faea's origins were dimly traced to the Polynesian Outlier of Luangiua.

Originally, Nga Ariki were confined to the lands of Uta, the inner shore of the lake (Te Roto). It was this restriction in resources that led to the desire of Nga Ariki to make war on their neighbours. As Firth writes:

They had in Uta only dry ground, no swampy ground suitable for the growth of taro, giant taro, and other kinds of moisture-loving foods. ... Time and again, I was told how day by day they and their households saw the scrapings of giant yam from the cooking-houses of their Nga Ravenga neighbours float past them on the waters of the lake. Feeling the pinch of hunger they collected these scrapings, and baked them for food in their own ovens. Further irritation was given to the chiefs by the fact that Nga Ravenga, while cognisant of their 
plight, did not send them any food, as courtesy dictated. ... Moved by the shortage of food, Nga Ariki conceived the idea of attacking Nga Ravenga and seizing their lands. (Firth 1961: 131-32)

A successful surprise attack led to the slaughter of every Nga Ravenga person, save the infant son of the Nga Ravenga chief, whose mother (a daughter of the Ariki Kafika) managed to carry him off to his grandfather who protected him; the child would become the founding ancestor of the Fangarere lineage. Nga Ariki added the Ravenga coastal lands to their holdings, and peace reigned for a generation. But then at the instigation of Fanamoea, an ancestor of the Marinoa lineage, and some others of Nga Ariki, it was decided to attack Nga Faea and seize the fertile western flatlands with their orchard gardens. This time there was no element of surprise, and Nga Faea struggled to defend themselves. The conflict is described in considerable detail (Firth 1961: 138-42), including the struggles of the great Faea warrior $\mathrm{Pu}$ Perurua (whose backrest stone still stands at Takaritoa) with Niupani, the Ariki Tafua of that time. Realising that defeat - and death-were imminent, Nga Faea took to their canoes and abandoned their lands to Nga Ariki.

The women and children were in the canoes; many of the men swam alongside. According to one account, the canoes were decorated with barkcloth streamers, as if it were a gala ritual occasion. Wailing, the folk of Nga Faea abandoned the land, some of them supporting their chief [Tiako] on the deck of his vessel, holding him aloft in their arms, in the gesture of supreme respect which the Tikopia pay to men of rank. ... So they went from sight, to be lost forever from the knowledge of men. (1961: 139)

In fact, not every single Nga Faea departed or was killed. Two sons of the Nga Faea chief Tiako were sent by their father to go to the Ariki Kafika, to assist in the transfer of the sacred rituals of the Atua i Takarito, where the stone of the Octopus God was kept, ritually washed and "invoked for its powers in producing plenty of fish" (1961: 141). These lads and some others gave rise to the present houses of Fasi, Siku and Torokinga. As Firth writes: "The ancestral connection with Nga Faea was still a living thing to those folks in 1929. Pa Torokinga said in telling me that story of his lineage, 'I am a Faea"' (1961: 142).

On the basis of the genealogies, Firth calculated that these events "can be given plausible dating - about 1725 A.D. and 1700 A.D. respectively" (1961: 160). Not only did our radiocarbon dating of the Nga Faea temple site agree with this genealogically based calculation, as I have already mentioned, but the archaeological and paleoecological work that we accomplished in 1977-78 put these events into a context that explains why Nga Ariki were 
driven to take the drastic measures they did to gain mastery of the island. What we discovered was that until quite late in the island's prehistory, the present lake Te Roto was an embayment open to the sea, with a fringing reef that supported a rich supply of shellfish and fish. Between AD 1600 and 1800 , probably in relation to one or more cyclone and storm-surge events, the sandy tombolo or beach ridge separating Te Roto from the sea accumulated, changing the ecology from that of a marine estuary to a brackish lake (Kirch and Yen 1982: 346-49, 354; see also Kirch and Swift 2017: 320). The rich shellfish beds died off; even canoe access through the reef to the open sea may have been cut off, depriving Nga Ariki of marine resources entirely. Far from being the stories of a "mythical people filling a mythical role", the accounts that Nga Ariki felt "hemmed in" at Uta, with its stony ground, and their resource base visibly dwindling, are rooted in the island's real, empirically verifiable historical ecology.

The archaeologically documented history of human occupation on Tikopia, based on radiocarbon dating, extends back to between 1046 and 769 BC (Kirch and Swift 2017), and is divisible through successive changes in material culture into three main phases, the Kiki, Sinapupu and Tuakamali periods (Kirch and Yen 1982). It was only in the third phase, the Tuakamali, the beginning of which we date to cal AD 1158-1212, that the arrival of Polynesian immigrant groups with distinctive Western Polynesian artefacts (basalt adzes of Sāmoan type, pearl-shell trolling hooks, distinctive beads, and a few obsidian flakes of Tongan origin) appear. Tikopia oral narratives of the tara tupua kind, indexed to family genealogies (e.g., Firth 1936, genealogies I, II and III), extend back no more than about 13 generations prior to Firth's time, or around $\mathrm{AD} 1600$ using his method of calculation ( 25 years per generation). These traditions thus pertain only to the latter part of the Tuakamali period. The traditions have their limitations; they cannot take us back to the earliest eras of the Tikopia past. But what they do offer us is a richly detailed window into the final few centuries in the long progression of historical events that shaped the Tikopia known to ethnography. To arrogantly dismiss these traditions as simply myth is to deny the Tikopia their own rich past. ${ }^{10}$

\section{NIUATOPUTAPU AND THE TONGAN MARITIME EMPIRE}

Niuatoputapu, situated at the northern end of the Tongan archipelago and closer to Sāmoa than to Tongatapu, together with nearby Niuafo 'ou, is an outlier of the far-flung "Tongan maritime empire" that in protohistoric times extended as far as 'Uvea, also incorporating the Vava' $u$ and Ha'apai island groups (Guiart 1963; see also Aswani and Graves 1998). I had the privilege of conducting an archaeological study of Niuatoputapu over the course of seven months in 1976 (Kirch 2015: 101-15), between my fieldwork in Futuna and Tikopia. 
A small island of about $15.2 \mathrm{~km}^{2}$ with a central volcanic ridge surrounded by an extensive apron of uplifted coral reef and lagoon, Niuatoputapu is slightly more than three times larger than Tikopia. And as on Tikopia, the archaeological record proved to be both long-extending back to an initial Lapita occupation of around 850-900 BC - and rich in the abundance and diversity of material traces of ancient human activity. But there is a major difference between the archaeological landscapes of these two small islands, for while on Tikopia the stone structures such as those of the Nga Faea temples are of small scale and prosaic, on Niuatoputapu such features are frequently of a scale that can only be referred to as monumental.

The conspicuous monuments dispersed over the Niuatoputapu landscape consist of a variety of mounds of sand or earth excavated out of nearby borrow pits and heaped up into large rectangular or circular edifices. The 95 structures I recorded could be divided into two main classes: mounds whose sides are faced with either natural stones or quarried slabs of coral limestone or beachrock; and unfaced mounds, some of which are paved and others unpaved (with the latter in some cases having a central depression) (Kirch 1988: 44-45, Fig. 23). I estimated the volume of the largest unpaved mound to be $2,518 \mathrm{~m}^{3}$; many have lengths or diameters in the range of 15-28 m (Kirch 1988, Table 3). In height, most mounds stand between 0.5 and $1 \mathrm{~m}$, although the larger ones rise $3-4 \mathrm{~m}$ above the surrounding terrain. These constructions represent a significant labour investment, in the digging out and heaping up of earth and sand, and in the quarrying, hauling, facing and trimming of retaining stones, many of which had to be extracted from beachrock quarries along the shoreline.

The functions of these mounds within traditional Tongan culture and society is fairly well established through the ethnohistoric record (McKern 1929). In general, the faced mounds served as burial facilities, either fa itoka where multiple individuals of an extended family or lineage were interred over an extended period, or in the case of chiefs or other prominent individuals, constructed for their exclusive interment. The term langi is sometimes applied to the more elaborate mounds with carefully prepared, cut-and-dressed limestone facades. The unfaced mounds (sia) are thought to have been used mainly in two ways: as sitting platforms for persons of high rank ('esi), or in the case of mounds with a central depression, as elevated "stages" for the chiefly sport of pigeon snaring (sia heu lupe). Many of the burial mounds (but not all of them) are located in and around the presentday villages, whereas most of the putative pigeon-snaring mounds are found around the island's perimeter, a zone where the Eugenia forests that provide the pigeons' favoured fruit are concentrated.

After seven months of fieldwork, it was clear that Niuatoputapu had at one time been under the domination of a regime powerful enough to induce, 
or coerce, the population to undertake remarkable architectural feats that indelibly inscribed the landscape with these monuments. But when had this activity taken place, and over how long a period, and to what ends? The answers to these questions were not immediately evident. The distribution of many of the pigeon-snaring mounds on former reef flats that had only fairly recently been tectonically uplifted provided one hint that these monuments probably dated to the more recent than truly distant past. With permission of the chief Telai, we excavated one of the stone-faced burial mounds, at Houmafakalele. Radiocarbon dating one of the three interments yielded an age estimate of cal AD 1420-1815 (Kirch 1988: 129-38, Table 13, $1 \sigma$ age range), placing this structure within the protohistoric period.

The Niuatoputapu people with whom we lived and worked in 1976 were well aware of these monuments, and could often give us proper names for some of the more elaborate mounds. Yet in contrast with Tikopia, there was a surprising dearth of traditional knowledge as to who was buried within particular mounds, who might have resided upon them, or who had engaged in the chiefly pigeon-snaring competitions. The last holder of the Ma'atu title - paramount lord of Niuatoputapu - had passed away in 1935, the title lapsing thereafter. The hou 'eiki 'chiefs', such as Telai of Hihifo Village where we resided, seemed to have little knowledge of, or interest in, these decaying monuments of a past era.

It was only after returning to Honolulu and beginning to work up my materials in the Bishop Museum that I was able to put this rich monumental landscape into the context of a traditional narrative history, thanks primarily to the corpus of material collected by Edward Winslow Gifford during the Bishop Museum's Bayard Dominick Expedition of 1920-21 (Gifford 1929, MS). Gifford had been given access by the then young Queen Sālote and by Prince Consort Tungi to the Tongan royal archives, including the genealogies of the Tamaha (sacred sister's daughter of the Tu'i Tonga) as well as several manuscripts containing traditional lore. Gifford's synthesis of these materials provides the basis our understanding of Tongan history through the lens of the chiefly oral narratives. His baseline research has been more recently augmented by Bott (1982) and Kaeppler (1971a, 1971b).

The clues as to when Niuatoputapu was brought into the orbit of the so-called Tongan "maritime empire" are contained in the Tongan chiefly genealogies and their associated traditions (see Kirch 1984: 223-42, 1988: 8-13). The Ma'atu title holders, who ruled over Niuatoputapu until 1935, originated from a junior branch of the Fale Fisi (House of Fiji), the offspring of unions between the sacred Tu'i Tonga Fefine and a Fijian chiefly line. The Tu'i Tonga Fefine Sinaetakala-'i-Langikela married the Fijian chief Tapu'osi; their male child Fonomanu in turn married the Tu'i Tonga Fefine 'Ekutongapipiki, who bore a son named Latumailangi. As related by Bott, 
... the Tu'i Tonga sent Latumailangi to Niuatoputapu to see whether he could secure the loyalty of the people there. He succeeded in doing so, and became the great 'eiki ['chief'] of Niuatoputapu, almost an independent line. He changed his name to Utuma'atu shortly after his arrival. There were a number of older titles already in existence there when Latumailangi arrived; all have become subordinate. It is possible that some may have been created after he arrived (Vivili, Tafea, Telai) ... . (Bott 1982: 106)

If we apply the same kind of temporal estimate that Firth used in calculating time spans for the Tikopia genealogies, the 11 generations of Ma'atu titleholders would take us back to the middle of the 17th century. It seems no coincidence that when the Dutch voyagers Schouten and Le Maire touched at Niuatoputapu in 1616 (the first Europeans to land there), they report that the island's "king" was called by his people "Latou" (Schouten 1619). Was Latumailangi himself ruling Niuatoputapu at the time of the Dutch visit? We cannot be completely certain, but it seems entirely plausible. A 17th-century assimilation of Niuatoputapu into the Tongan maritime empire fits well with the radiocarbon dating of the Tongan-style burial mound at Houmafakalele. Both the archaeological record and the Tongan traditions converge on the interpretation that Niuatoputapu was brought within the orbit of the Tongan maritime empire during the 17th century, and that the many monuments in classically Tongan style, such as burial mounds and pigeon-snaring mounds, were most likely constructed during the 17 th to 18 th centuries.

Recent work by my colleagues Geoffrey Clark and David Burley, along with their students, has further integrated the genealogies and traditions of the Tu'i Tonga, Tu'i Ha'atakalaua and Tu'i Kanokupolu lines with the increasingly well-dated, archaeological evidence for the rise of an archaic state on Tongatapu Island (Burley 1994; Clark 2016; Clark and Reepmeyer 2014; Clark et al. 2008). I tentatively explored these genealogies many years ago in The Evolution of the Polynesian Chiefdoms (Kirch 1984: 223-30), arguing that they provided a history of the rise of the Tongan dual paramountship. I showed that it was possible to link the chiefly genealogies with archaeological evidence for the sequence of construction and elaboration of the $\mathrm{Tu}^{\text {' }} \mathrm{i}$ Tonga capital at Lapaha, with its famous langi burial tombs, fortification works and stone canoe dock. Those correspondences between the traditions and the archaeological record are now well attested thanks to the additional work of Clark, Burley and their students at Lapaha and other sites. One remarkable discovery, recently made by Travis Freeland (2018), concerns an oral tradition relating to the first seat of the Tu'i Tonga line (prior to its move first to Heketa, and then to Lapaha), which is said to have been at Toloa, in central eastern Tongatapu. This is a shadowy period in the traditions, relating to the reigns of the first nine Tu'i Tonga titleholders. Using LiDAR aerial imagery Freeland identified a previously 
unreported complex of large earthen mounds at Toloa. The central mound, oriented nearly north-south, is a truly massive construction, $105 \mathrm{~m}$ long by $50 \mathrm{~m}$ wide, incorporating an estimated $10,356 \mathrm{~m}^{3}$ of earth (Freeland 2018: 131, Table 8). While Freeland's interpretation of this mound complex as the original Tu'i Tonga capital needs to be confirmed through subsurface excavation and dating, it nonetheless suggests that the Tongan royal traditions have an historical basis extending back in time as far as the 13th century.

MAUI AND HAWAI'I:

\section{CHIEFLY AGENCY IN EMERGING ARCHAIC STATES}

An exceptionally rich tradition of oral histories passed down from generation to generation in Hawai' $i$ was eventually put into written form in the 19th century (Fornander 1878; Kamakau 1961; Malo 1951). For various reasons, however, archaeologists in Hawai'i have all too rarely sought to link these mo 'olelo to the archaeological record, overlooking their potential significance. In the late 1990s, however, as I began to work on the problem of the emergence of "archaic states" in the islands (Kirch 2010), I found the indigenous Hawaiian traditions to be a rich lode of insights into the processes that transformed Hawaiian society between the late 16th century and the early European-contact period. In A Shark Going Inland Is My Chief, I endeavoured to weave these rich traditions together with the archaeological evidence to yield a more compelling story than either source could provide independently (Kirch 2012). I will touch here upon just one small part of that rich history, focusing on the early Maui ruler Kiha-a-Pi'ilani, and how we may trace some of his "footprints" in the archaeological record.

The mo 'olelo of Maui ali 'i nui 'paramount chief' Pi'ilani-and of his two sons who fought to the death over the succession to the kingship - is as central to the history of Maui as that of Līloa and 'Umi is to Hawai'i Island (Fornander 1878, Vol. II: 205-7; Kamakau 1961: 1-21; Valeri 1985). In fact, the two royal houses were linked by bonds of marriage, for Pi'ilani's daughter

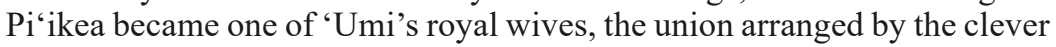
priest Kaleiokū to cement a political alliance between Hawai' $i$ and Maui.

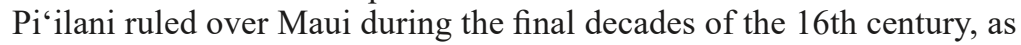
reckoned from his genealogy. Fornander tells us that it was under either Pi'ilani or possibly his father Kawaoka'ōhele that the entire island of Maui first became a unified polity. This initial unification was achieved peacefully, the Hāna chiefs acceding to the suzerainty of the Pi'ilani line, whose origins centred on west Maui. The ancient seat of the Pi'ilani clan of chiefs was Nā Wai Ehā, the "Four Waters" of Waihe'e, Waiehu, Wailuku and Waikapū, whose streams fed canals that watered extensive taro irrigation works on the alluvial flats, giving Kawaoka ōhele, and his son Pi'ilani, their economic base. Pi'ilani's royal residence of Hale Ki' $\mathrm{i}$ in Wailuku overlooked the 'Iao Stream, at the centre of this intensive production zone. Although sometimes 


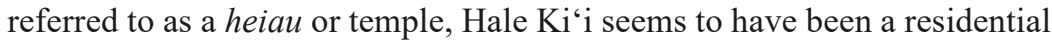
terrace, with the luakini heiau 'temple of human sacrifice' being nearby Pi'ihana Heiau (Kolb 1999).

Pi'ilani had two high-ranking sons by his wife La'ieloheloheikawai (a sacred chiefess from $\mathrm{O}^{\prime} \mathrm{ahu}$ ), the oldest named Lono-a-Pi'ilani (hereafter Lono), and a younger son named Kiha-a-Pi'ilani (hereafter Kiha). Kiha had been raised by his maternal kinsfolk in the royal court of $\mathrm{O}^{\prime}$ ahu Island, whereas Lono - following the norms of patrilineal succession - had been groomed as the heir to the Maui kingship. On his deathbed, Pi'ilani declared that Lono would succeed him as ali ' $i$ nui of Maui, commanding Kiha to live peacefully under his older brother.

It did not take long for jealousy to arise between the royal siblings. Lono became envious at the way in which Kiha was developing his irrigated fields in Waihe'e Valley. Usurpation being an age-old theme in Polynesian politics, Lono suspected that Kiha was plotting to steal the kingdom. Lono began to humiliate Kiha, one day throwing a bowl of briny water filled with octopus into Kiha's face. Realising that Lono was plotting to kill him, Kiha fled to Moloka'i. Kamakau (1961: 22) identifies Paku'i, a large stone terrace at Manawai on Moloka'i's south coast, as the "fortress" where Kiha-a-Pi'ilani resided while on the island. Bishop Museum archaeologist John Stokes mapped Paku'i in 1909 (Stokes MS), and I had the opportunity to visit the structure a few years ago (Fig. 4). In its layout, Paku'i closely resembles Hale $\mathrm{Ki}^{`} \mathrm{i}$, consisting of a massive stone terrace supporting several smaller superstructures (presumably residential structures). It seemed to me to have been built on the same basic architectural plan.

Kiha evaded the warriors sent by Lono, fleeing to Lana' $i$, and then secretly stealing back to Maui, making his way to the dry sweet-potato farmlands of upland Honua'ula and Kula, on the broad slopes of Haleakalā, masquerading as a commoner among the farmers of the uplands, a ruse that failed when rainbows frequently appeared over Kiha's head (the sign of a high chief). During this time, Kiha demonstrated his skills both as a cultivator and leader of men.

Kiha left Kula for Hāna, a district then ruled over by Ho'olaemakua, a warrior chief fiercely loyal to Lono. Kiha thought that if he could convince Ho'olaemakua to turn against Lono and support his own cause, he would have a powerful ally. Kiha was handsome, with, as Kamakau tells us, eyes "as bright as those of a moho "ea bird". He had mastered the art of surfing in his youth, riding the long breakers at Waikīkī. As it happened, Ho 'olaemakua had a daughter, Koleamoku, who also loved to surf. Koleamoku was determined to have Kiha as her husband. They eloped, and Koleamoku began living with Kiha in his house at Kawaipapa. When her father Ho'olaemakua heard what had happened, he flew into a rage, for he had placed a kapu or taboo on her which could only be lifted by the king, Lono-a-Pi'ilani. Ho'olaemakua disowned Koleamoku. 


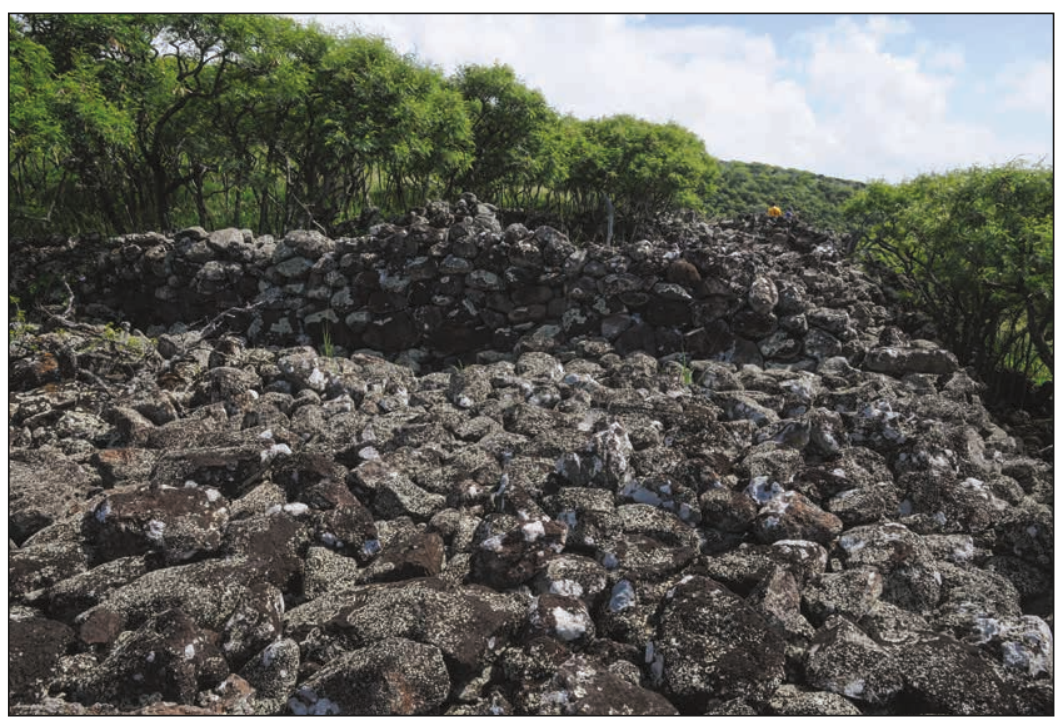

Figure 4. The stone terraced platform of Paku'i on Moloka'i Island is said to have been the residence of Kiha-a-Pi'ilani.

Koleamoku bore Kiha a son, whom they lovingly raised. Sensing that Ho'olaemakua's anger would have subsided, Koleamoku went to her father's house to present him with his grandson, and to offer a feast of reconciliation. The Hāna chief greeted his daughter and his infant grandson with great affection, but refused to take his daughter's side.

Kiha now swore vengeance against his father-in-law, and resolved to cross the stormy 'Alenuihāhā Channel to Hawai' $i$, where his sister Pi'ikea was married to 'Umi, now king of that largest island. He would seek 'Umi's assistance in gaining control over Maui. Arriving at the royal residence of Kamakahonu, Kiha went in search of his sister. Urged on by Pi'ikea, 'Umi agreed to help Kiha overthrow Lono and become the ruler of Maui. A year was spent constructing a fleet of war canoes to transport the Hawai' $i$ forces across the channel. 'Umi and Kiha took the battle straight to Hāna, where Ho'olaemakua had refused to lend his support to Kiha. The old warrior chief had prepared his fortress hill of Ka'uiki, standing sentinel over Hāna Bay (Fig. 5). When the fleet of war canoes filled with Hawai'i Island warriors arrived, they were held off by the barrages of sling stones cast by the Maui warriors from their vantage point on Ka'uiki, unable to dislodge Ho'olaemakua's forces. 
Under the cover of darkness, Pi'imaiwa'a, the famous warrior who had helped 'Umi kill Hākau and gain control over Hawai'i, crept up close to the steep entrance to the hilltop fortress. It seemed to be guarded by a huge warrior. Pi'imaiwa'a lanced his spear into the "warrior", but it did not move. Climbing closer, he hit the giant with his club. It stood motionless. Pi'imaiwa'a realised that this was a dummy built of wood and wicker, to fool the invaders at night so that the Maui defenders could rest. He sent word for the Hawai' $i$ warriors to follow him up the steep ladder into the fortress where they fell upon the slumbering Maui forces. Many were killed, or leapt to their deaths off the steep cliffs encircling the hill. In the darkness a few escaped, including Ho'olaemakua. The old chief was finally hunted down at Kapipiwai, tortured and killed. His hands were brought back to Kiha to confirm his death.

During the battle at Hāna, Lono-a-Pi'ilani had remained safely on west Maui at Wailuku, the old seat of the Pi'ilani line. When he heard that the fortress of Ka'uiki had fallen, and that Ho'olaemakua had been captured and killed, he was filled with dread. By the time Kiha and 'Umi with the Hawai' $i$ forces arrived at Wailuku, Lono was dead, evidently of sheer fright.

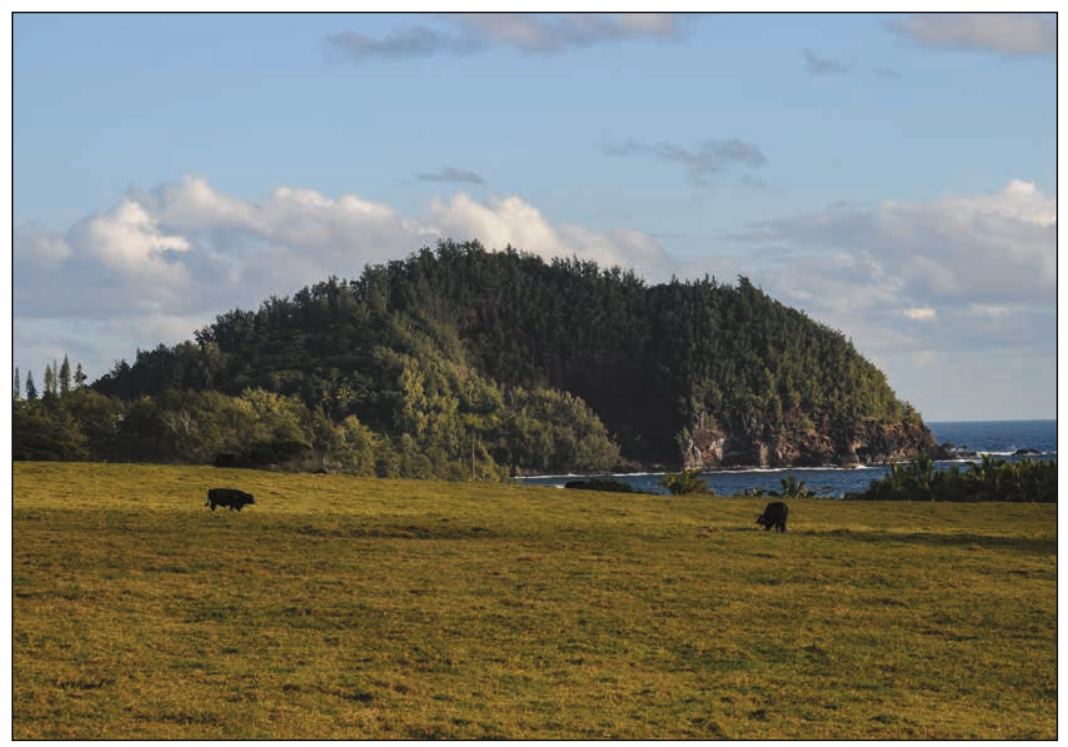

Figure 5. The fortress hill of Ka'uiki at Hāna, Maui, where Ho'olaemakua was defeated by the forces of 'Umi and Kiha-a-Pi'ilani. 
Kiha-a-Pi'ilani was now the undisputed lord of Maui. As was the custom, he divided the districts and ahupua ' $a$ 'subdistict land division' among his loyal followers and warriors. 'Umi and his fleet returned to Hawai' $i$, leaving Maui under the rule of his brother-in-law. It was probably at this time that Kiha had the great terrace at Pi'ilanihale Heiau constructed, making it his royal centre and principal luakini. The structure is similar in basic design to the older residence at Hale Ki' $\mathrm{i}$, but built on a much grander scale (Kolb 1999). Yet another archaeological expression of Kiha's new dominance over all of Maui was the rapid expansion of a system of mid-sized temples, many of which have been dated through U-series dating of coral offerings to a narrow time span from the end of the 16th into the 17th centuries, corresponding with Kiha's reign and that of his son Kamalālāwalu (Kirch and Sharp 2005; Kirch et al. 2015). The descendants of Kiha-a-Pi'ilani would continue to rule over Maui in an unbroken succession until the end of the 18th century, when Kamehameha the Great took possession of the island during his conquest of the archipelago.

In recounting this oral tradition of Kiha-a-Pi'ilani, I purposefully left in some of the little details that give this history such a distinctly Polynesian cultural form - such as the frequent appearance of rainbows over Kiha's head and the ruse of the giant warrior dummy at the Ka'uiki fortress. It is just such details that have persuaded some Western scholars that traditions such as these should be treated as myth rather than history. In my view, however, these details merely serve to situate the real historical actor-in this case Kiha - within a cultural context that would have been perfectly reasonable to an indigenous Hawaiian listener. I see no reason to think that Kiha was anything other than the actual ruler of Maui in the early 17th century; and indeed, we can trace his "footprints" to several key archaeological sites both on Maui and on Moloka' $i$.

$$
* * *
$$

Through these four examples drawn from my own field experiences, I have tried to demonstrate how Polynesian oral narratives or traditions - in particular those that are linked to a chronology defined by lineage or chiefly genealogies - have a real historical basis that can often be integrated with material evidence derived from archaeological survey and excavation to arrive at a fuller, more nuanced account of the past. This is by no means to deny the mythological content of much oral tradition (especially that concerned with cosmology), or to insist that all oral traditions are historical. Clearly they are not. But when a particular corpus of traditions, such as the tara tupua of Tikopia, treat in detail of the actions of men and women who 
are linked in a chronological chain to present descendants, why should we not regard these as reasonable sources of historical knowledge? And in particular, when such accounts can be referenced to specific localities and indeed sometimes to particular archaeological sites and structures, then it seems to me that the potential for an integration of these two different ways of historical "knowing" should not be ignored.

But the "voices on the wind" and the "traces in the earth" do not tell us the same things about the past, and it is precisely these differences that should make us want to incorporate both sources, rather than rely exclusively on one or the other. Archaeology rarely has the ability to resolve history at the level of the individual actor, or even of discrete events. Archaeological landscapes are notorious for being "palimpsests", their surfaces partially erased and written over repeatedly. Even the best stratified sites encapsulate months, years or even centuries within a single feature or layer. Advances in radiocarbon and $U$-series dating have helped to greatly refine our chronologies in recent years, but our temporal resolution remains at the best plus or minus the length of a human generation. Given these constraints and limits to our methods, we archaeologists tend to write history in terms of broad "processes" and "trends". We trace the major shifts in settlement patterns, in economic systems, in population growth or decline, in stylistic changes in material culture. Ours is a history of what Fernand Braudel called the longue durée, the long run (Braudel 1980).

Oral narrative history of the Polynesian kind, in contrast, is essentially a history of the événementiel - the event, as plotted and enacted by individual actors who are urged on by their own desires, emotions, fears and dreams. It is an "insider" history (an emic history, to use the old anthropological distinction between emic and etic), one informed by indigenous knowledge, and acted out within the culturally prescribed norms (or sometimes, in flagrant violation of culturally acceptable behaviour). Oral history takes us where archaeology can never go, at least not by itself. But then archaeology offers a wider perspective to the historical particulars, allowing us to see them as part of the broader sweep of human affairs. In short, archaeology gives us process; oral tradition gives us agency. Together they give us a history that is both culturally nuanced and comparatively contextual.

\section{NOTES}

1. In the introduction to his monograph on the archaeology of Nuku Hiva, Suggs comments as follows on the use of oral traditions to determine settlement dates for Polynesian islands: "One of the most profound effects of the concentration on tradition on the part of early writers was their tendency to rely almost 
completely on genealogies for purposes of dating. This reliance on genealogies shortened the perspective of all prehistorians in Polynesia, with the result that it became generally accepted that the Polynesian arrival in Eastern Polynesia was very recent and that no island had been settled for more than one millennium" (1961: 11).

2. It is, of course, more than a little ironic that we have now, with the hindsight of many advances in radiocarbon dating of archaeological materials, come around to the conclusion that Suggs's early dates were almost certainly the result of samples derived from old wood (in some cases probably driftwood) with large in-built ages that did not accurately date the age of initial human arrival on Nuku Hiva. The most recent high-precision dating for the Hane site on 'Ua Huka Island indicates human colonisation of the northern Marquesas around AD 950 (Conte and Molle 2014), essentially the same as Handy's estimate based on the genealogies!

3. To be sure, Suggs did not call for the outright rejection of "traditions" in Polynesian anthropological research, admitting that these could provide "a body of general data which can be used ... as a kind of paleo-ethnology for the culture in question, to aid in the interpretation of the cold facts and sequences of archeology" (1960: 771).

4. Hiroa's reaction to this is evident in his pithy remarks regarding "functional and psychological methods", in his 1943 overview of Polynesian anthropology: "Another approach to the study of native peoples is what has been termed the functional method. It is primarily associated with the names of Malinowski and Radcliffe-Brown, who, like Moses and Aaron, lead their followers into a land of greater promise. The greater field of promise lies in ignoring the bondage of the historical past and devoting attention to the functioning present" (1945: 127).

5. I myself had occasion to be subjected to Edmund Leach's famously cutting prose, when at the 1983 Pacific Science Congress in Dunedin, at a symposium in which Leach was presenting I had the temerity to suggest that he was wrong about his critique of Firth's treatment of the Tikopia traditions as history. Having recently conducted archaeological fieldwork in Tikopia, I had plenty of evidence that the Nga Faea had indeed been real people, for I had excavated one of their temple houses. To this statement Leach vociferously boomed from the podium, "That is like saying that King Arthur was a real person!" (dismissed, young American archaeologist).

6. One significant exception that must be acknowledged is the work of José Garanger in Vanuatu, where he explicitly drew upon oral traditions in his archaeological research, especially at the burial site of Roy Mata on Retoka Island (Garanger 1972a, 1972b).

7. Alofi Island is known to have been populated at the time of the arrival of the Dutch voyagers Schouten and Le Maire in 1616, as the chief of Alofi and his warriors came across to visit the foreigners (Kirch 1994: 237). Père Chanel visited Alofi in July of 1838, finding abundant evidence of recently abandoned habitations. He was told that the Alofi people had been exterminated during several wars under the rule of Veliteki, paramount chief of Asoa. 
8. Daniel Frimigacci (1990) later explored these sites in greater detail than I was able to, incorporating Futunan oral traditions into his interpretations. Frimigacci's attention to oral tradition no doubt reflects the influence of his mentor, José Garanger.

9. Aided by my prior efforts to gain fluency in Tongan (during my 1976 fieldwork on Niuatoputapu), I was fairly rapidly able to gain conversational ability in Tikopian in 1977. This allowed me to speak directly with the older people, such as the Ariki Tafua and Ariki Taumako, who did not speak either English or "NeoMelanesian" pidgin.

10. A structuralist interpretation of Tikopia society with its four clans was advanced in a short monograph by Anthony Hooper (1981). As with Leach's critique of Firth, Hooper (although he never worked on Tikopia or with Tikopia informants) effectively dismisses the historical basis of Tikopia traditions as a starting assumption. He therefore arrives at the conclusion that "the Tikopia conceive their social and cultural order as a deliberately created thing, something closer to our notions of a work of art than to the precipitates of the chance fortunes of a historical past" (1981: 42). In fact, my own experience of ethnographic work on and with the Tikopia was precisely the opposite - that the Tikopia are acutely aware of and constantly situate themselves within the rich history that is simultaneously inscribed in their traditions and on their landscape.

\section{REFERENCES}

Arii Taimai, 1964. Mémoires d'Arii Taimai. Publication de la Société des Océanistes No. 12. Paris.

Aswani, S. and M.W. Graves, 1998. The Tongan maritime expansion: A case in the evolutionary ecology of social complexity. Asian Perspectives 37 (2): 135-64.

Bott, E., 1982. Tongan Society at the Time of Captain Cook's Visits: Discussions with Her Majesty Queen Sālote Tupou. Polynesian Society Memoir 44. Wellington.

Braudel, F., 1980. On History. Translated by S. Matthews. Chicago: University of Chicago Press.

Buck, P.H. (Te Rangi Hiroa), 1938. Vikings of the Sunrise. Philadelphia: J.B. Lippincott Co.

Burley, D.V., 1994. As a prescription to rule: The royal tomb of Mala'e Lahi and 19th-century Tongan kingship. Antiquity 68 (260): 504-17.

Burrows, E.G., MS. 1932. Field notebooks I-IV (March-June 1932). Archives of the Bernice P. Bishop Museum. Honolulu. 1936. Ethnology of Futuna. Bernice P. Bishop Museum Bulletin 138. Honolulu. 1937. Ethnology of Uvea. Bernice P. Bishop Museum Bulletin 145. Honolulu.

Clark, G., 2016. Chiefly tombs, lineage history, and the ancient Tongan state. Journal of Island and Coastal Archaeology 11 (3): 326-43.

Clark, G., D. Burley and T. Murray, 2008. Monumentality and the development of the Tongan maritime chiefdom. Antiquity 82 (318): 994-1008.

Clark, G., and C. Reepmeyer, 2014. Stone architecture, monumentality, and the rise of the early Tongan chiefdom. Antiquity 88 (342): 1244-60. 
Conte, E. and G. Molle, 2014. Reinvestigating a key site for Polynesian prehistory: New results from the Hane dune site, Ua Huka (Marquesas). Archaeology in Oceania 49: 121-36.

Firth, R., 1936. We, the Tikopia. London: George Allen and Unwin.

-1961. History and Traditions of Tikopia. Polynesian Society Memoir 33. Wellington.

-1967. The Work of the Gods in Tikopia. 2nd Edition. London: Athlone Press.

Fornander, A., 1878. An Account of the Polynesian Race. 3 Vols. London: Trübner \& Co.

Freeland, T., 2018. Monumental Architecture and Landscape History of the Tongan Classical Chiefdom. Unpublished PhD Dissertation, Simon Fraser University. Burnaby, Canada.

Frimigacci, D., 1990. Aux temps de la Terre Noire: Ethnoarchéologie des îles Futuna et Alofi. Paris: Peeters.

Garanger, J., 1972a. Archéologie des Nouvelles-Hébrides. Publication de la Société des Océanistes No. 30. Paris.

1972b. Mythes et archéologie en Océanie. La Recherche 21: 233-42.

Gifford, E.W., 1929. Tongan Society. Bernice P. Bishop Museum Bulletin 61. Honolulu.

MS. 1920-21. Manuscript notes from the Bayard Dominick Expedition. Archives of the Bernice P. Bishop Museum. Honolulu.

Gregory, H.E., 1921. Report of the director for 1920. Occasional Papers of the Bernice P. Bishop Museum 8(1): 1-28.

Grey, G., 1885. Polynesian Mythology and Ancient Traditional History of the New Zealand Race. Auckland: Brett.

Guiart, J., 1963. Structure de la chefferie en Mélanésie du Sud. Paris: Institut d'Ethnologie, Musée de l'Homme.

Handy, E.S.C., 1923. The Native Culture in the Marquesas. Bernice P. Bishop Museum Bulletin 9. Honolulu.

Hiroa, T.R. (P.H. Buck), 1932. Ethnology of Tongareva. Bernice P. Bishop Museum Bulletin 92. Honolulu.

-1934. Mangaian Society. Bernice P. Bishop Museum Bulletin 122. Honolulu. 1938. Ethnology of Mangareva. Bernice P. Bishop Museum Bulletin 157. Honolulu.

-1945. An Introduction to Polynesian Anthropology. Bernice P. Bishop Museum Bulletin 187. Honolulu.

Hooper, A., 1981. Why Tikopia Has Four Clans. Occasional Paper No. 38. London: Royal Anthropological Institute of Great Britain and Ireland.

Kaeppler, A., 1971a. Rank in Tonga. Ethnology 10 (2): 174-93.

1971b. Eighteenth century Tonga: New interpretations of Tongan society and material culture at the time of Captain Cook. Man 6 (2): 204-20.

Kamakau, S., 1961. Ruling Chiefs of Hawaii. Honolulu: Kamehameha Schools Press. Kirch, P.V., 1975. Cultural Adaptation and Ecology in Western Polynesia: An Ethno-archaeological Study. Unpublished PhD dissertation, Yale University, New Haven. 
-1984. The Evolution of the Polynesian Chiefdoms. Cambridge: Cambridge University Press.

-1988. Niuatoputapu: The Prehistory of a Polynesian Chiefdom. Thomas Burke Memorial Washington State Museum Monograph No. 5. Seattle: Burke Museum. 1994. The Wet and the Dry: Irrigation and Agricultural Intensification in Polynesia. Chicago: University of Chicago Press.

2010. How Chiefs Became Kings: Divine Kingship and the Rise of Archaic States in Ancient Hawai ' $i$. Berkeley: University of California Press.

-2012. A Shark Going Inland Is My Chief: The Island Civilization of Ancient Hawai $i$. Berkeley: University of California Press.

2015. Unearthing the Polynesian Past: Explorations and Adventures of an Island Archaeologist. Honolulu: University of Hawai'i Press.

-2017. On the Road of the Winds: An Archaeological History of the Pacific Islands Before European Contact. Revised and enlarged edition. Berkeley: University of California Press.

Kirch, P.V., R. Mertz-Kraus and W.D. Sharp, 2015. Precise chronology of Polynesian temple construction and use for southeastern Maui, Hawaiian Islands determined by ${ }^{230} \mathrm{Th}$ dating of corals. Journal of Archaeological Science 53: 166-77.

Kirch, P.V. and W.D. Sharp, 2005. Coral ${ }^{230} \mathrm{Th}$ dating of the imposition of a ritual control hierarchy in precontact Hawaii. Science 307 (5706): 102-4.

Kirch, P.V. and J.A. Swift, 2017. New AMS radiocarbon dates and a re-evaluation of the cultural sequence of Tikopia Island, Southeast Solomon Islands. Journal of the Polynesian Society 126 (3): 313-36.

Kirch, P.V. and D.E. Yen, 1982. Tikopia: The Prehistory and Ecology of a Polynesian Outlier. Bernice P. Bishop Museum Bulletin 238. Honolulu.

Kolb, M.J., 1999. Monumental grandeur and political florescence in pre-contact Hawai'i: Excavations at Pi'ilanihale Heiau, Maui. Archaeology in Oceania 34 (2): 71-82.

Krauss, B., 1988. Keneti: South Seas Adventures of Kenneth Emory. Honolulu: University of Hawaii Press.

Leach, E.R., 1962. Review of R. Firth, History and Traditions of Tikopia. Journal of the Polynesian Society 71 (2): 273-76.

Luomala, K., 1955. Voices on the Wind: Polynesian Myths and Chants. Honolulu: Bishop Museum Press.

Malo, D., 1951. Hawaiian Antiquities. Bernice P. Bishop Museum Special Publication 2. Honolulu.

McKern, W., 1929. Archaeology of Tonga. Bernice P. Bishop Museum Bulletin 60. Honolulu.

Reilly, M.P.J., 2003. War and Succession in Mangaia from Mamae's Texts. Polynesian Society Memoir 52 . Auckland.

Schouten, W., 1619. A Wonderful Voyage Round About the World. Facsimile reprint, 1968. New York: Da Capo Press.

Smith, S.P., 1910. Hawaiki: The Whence of the Maori, being an Introduction to Rarotongan History. Wellington: Whitcombe \& Tombs.

-1921. Hawaiki: The Original Home of the Maori, with a Sketch of Polynesian History. Auckland: Whitcombe \& Tombs. 
Sorrenson, M.P.K. (ed.), 1986-88. Na To Hoa Aroha, From Your Dear Friend: The Correspondence Between Sir Apirana Ngata and Sir Peter Buck, 1925-50. Three volumes. Auckland: Auckland University Press.

St Cartmail, K., 1997. The Art of Tonga. Honolulu: University of Hawai'i Press.

Stokes, J.F.G., MS. 1909. Heiau of Moloka'i. Unpublished manuscript. Archives of the Bernice P. Bishop Museum, Honolulu.

Suggs, R.C., 1960. Historical traditions and archeology in Polynesia. American Anthropologist 62 (5): 764-73.

1961. The Archaeology of Nuku Hiva, Marquesas Islands, French Polynesia. Anthropological Papers of the American Museum of Natural History Vol. 49, Part 1. New York.

Valeri, V., 1985. The conqueror becomes king: A political analysis of the Hawaiian legend of 'Umi. In A. Hooper and J. Huntsman (eds), Transformations of Polynesian Culture. Auckland: The Polynesian Society, pp. 79-104.

\begin{abstract}
Polynesian societies have long been noted for encoding their histories in the form of oral narratives. While some narratives are clearly cosmogonic or mythological in nature, others purportedly recount the affairs of real persons, chronologically indexed to chiefly and family genealogies. Late 19 th- and early 20th-century scholars such as Abraham Fornander and Te Rangi Hiroa relied upon such oral narratives to write the pre-European histories of various Polynesian societies. In the second half of the 20th century, however, archaeologists and cultural anthropologists alike have tended to dismiss the historical validity of oral narratives. Based on four case studies from Futuna, Tikopia, Niuatoputapu and Hawai'i, I reassess the linkages between oral narratives and the archaeological record, finding that in all cases there is strong evidence to support the view that the traditional narratives relate to real persons and events. Such traditional narratives typically do not extend farther back in time than three to four centuries, but for these later time periods they offer an invaluable resource - an indigenous perspective on island histories that complements and augments the empirical archaeological record.
\end{abstract}

Keywords: Polynesian archaeology, oral traditions, oral history, Polynesian genealogies, Futuna, Tikopia, Niuatoputapu, Hawai'i

\title{
CITATION AND AUTHOR CONTACT DETAILS
}

Kirch, ${ }^{1}$ Patrick Vinton, 2018. Voices on the wind, traces in the earth: Integrating oral narrative and archaeology in Polynesian history. Journal of the Polynesian Society 127 (3): 275-306. DOI: http://dx.doi.org/10.15286/jps.127.3.275-306.

${ }^{1}$ Correspondence: Department of Anthropology, 232 Kroeber Hall, University of California, Berkeley, 94720, USA. Email: kirch@berkeley.edu 